$\frac{\text { ROE/ID-11300 }}{\text { Explaion } 0}$

\title{
Explanation of Significant Differences for the Record of Decision for the Test Area North Operable Unit 1-10
}

Idaho Cleanup Project At the Idaho National Laboratory Site Idaho Falls, Idaho 
DOE/ID-11300

Revision 0

Project No. 23093

\section{Explanation of Significant Differences for the Record of Decision for the Test Area North Operable Unit 1-10}

January 2007 
SIGNATURE SHEET

Signature sheet for the Explanation of Signific ant Differences for the Record of Decision for the Test Area Nom th Operable Unit $1-10$ at the Idaho National Laboratory. between the U.S. Department of Energy and the U.S. Environmental Protection Agency. with concurrence by the Idaho Department of Environmental Quality
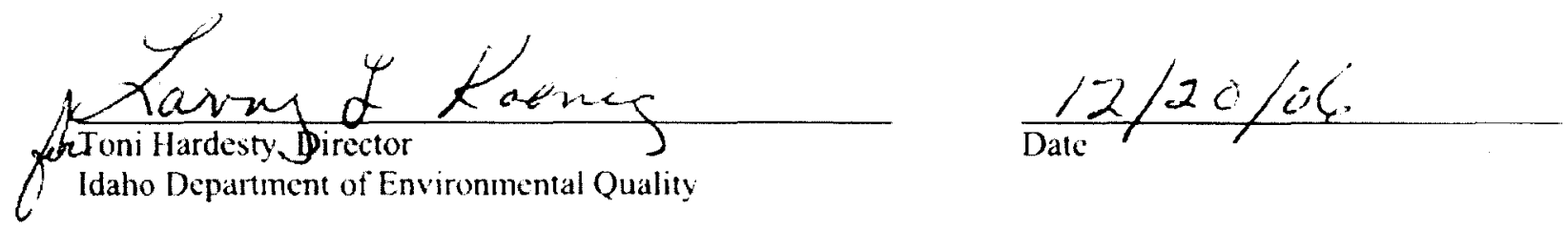


\section{SIGNATURE SHEET}

Signature sheet for the Explanation of Significan Differences for the Rerord of Decision for the Test Area North Operable Lint $1-10$ at the Idaho National Laboratory, between the ISS.

Department of Energy and the U.S. Fnvirommental Protection Agenc? with concurrence by the Idaho Department of Environmental Quality.

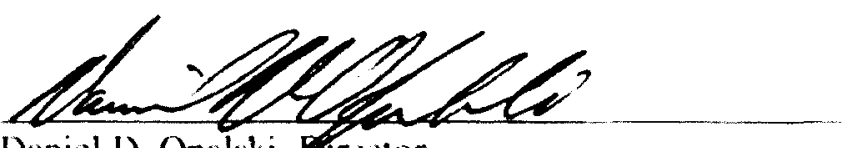

Daniel D. Opalski. Birector

Office of Environmental Cleanup

C.S. Environmental Protection Agency.

Region 10

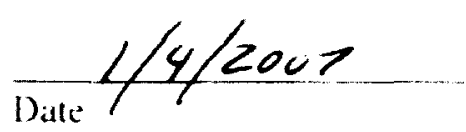




\section{SIGNATURE SHEET}

Signature sheet for the Explanation of Significant Differences for the Record of Deciston for the Test Area North Operable Unit 1-10 at the Idaho National Laboratory, between the U.S. Department of Energy and the U.S. Environmental Protection Agency, with concurrence by the Idaho Department of Environmental Quality
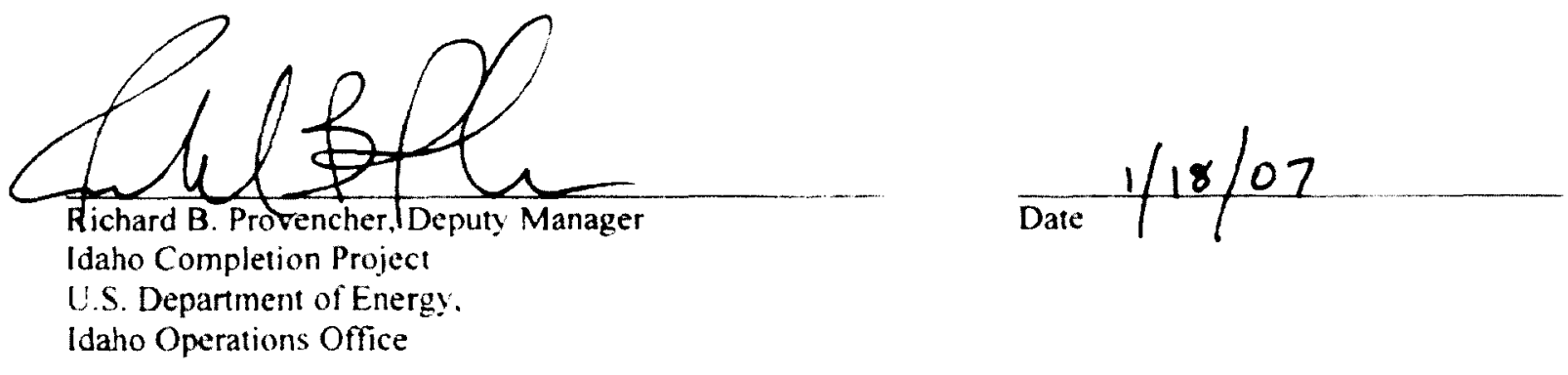

U.S. Department of Energy. 


\section{CONTENTS}

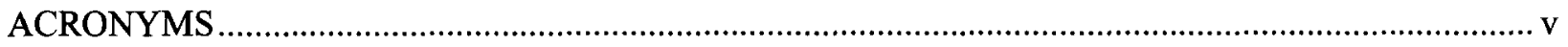

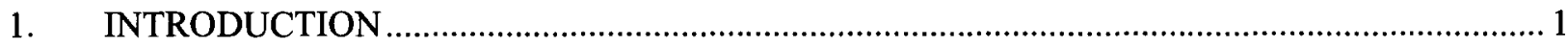

2. SUMMARY OF SITE HISTORY, CONTAMINATION, AND SELECTED REMEDY ............... 2

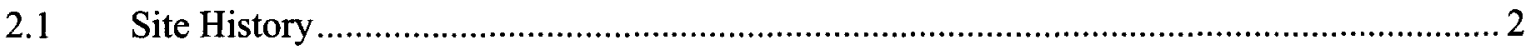

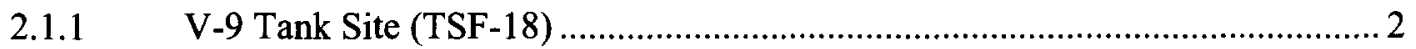

2.2 Contamination in Accordance with the 1999 Record of Decision ...................................... 5

2.3 Selected Remedy in Accordance with the 2005 Explanation of Significant Differences ..... 6

3. DESCRIPTIONS AND BASIS OF THE SIGNIFICANT DIFFERENCES ................................ 6

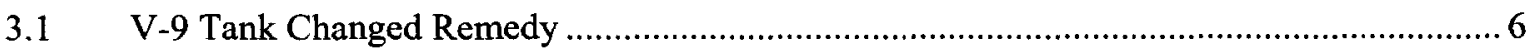

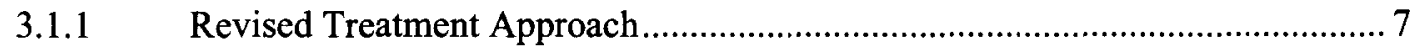

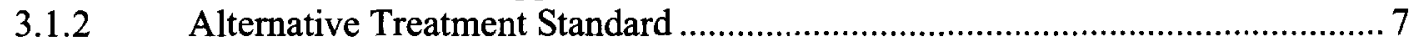

3.1.3 Addition of Potential Treatment Location................................................. 9

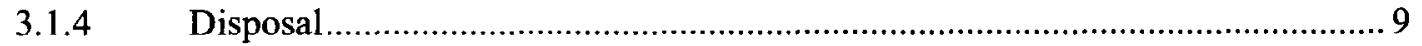

3.2 Rough Order of Magnitude Cost Estimate ................................................................... 9

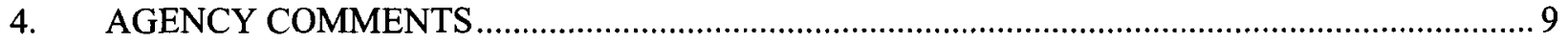

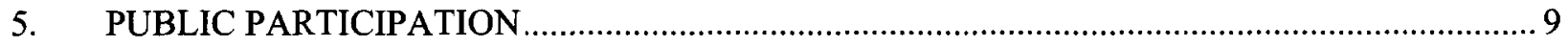

6. AFFIRMATION OF THE STATUTORY DETERMINATIONS …....................................... 10

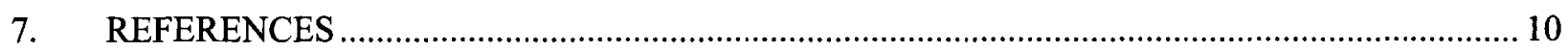

\section{FIGURES}

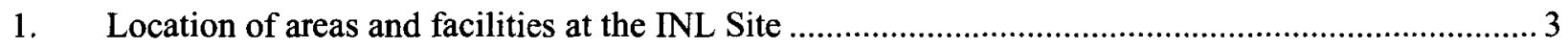

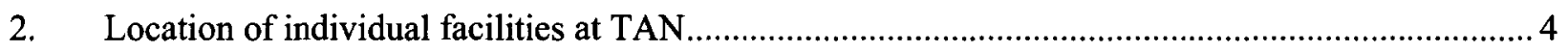

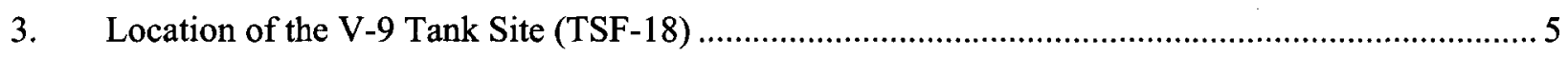

\section{TABLES}

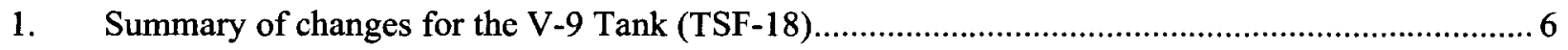




\section{ACRONYMS}

\begin{tabular}{|c|c|}
\hline AOC & area of contamination \\
\hline ARAR & applicable or relevant and appropriate requirement \\
\hline CERCLA & Comprehensive Environmental Response, Compensation, and Liability Act \\
\hline CFR & Code of Federal Regulations \\
\hline DEQ & Idaho Department of Environmental Quality \\
\hline DOE & U.S. Department of Energy \\
\hline EPA & U.S. Environmental Protection Agency \\
\hline ESD & Explanation of Significant Differences \\
\hline ICDF & Idaho CERCLA Disposal Facility \\
\hline IET & Initial Engine Test \\
\hline INL & Idaho National Laboratory \\
\hline LDR & land disposal restrictions \\
\hline LOFT & Loss-of-Fluid Test \\
\hline OU & operable unit \\
\hline PCE & tetrachloroethylene \\
\hline RCRA & Resource Conservation and Recovery Act \\
\hline ROD & Record of Decision \\
\hline SMC & Specific Manufacturing Capability \\
\hline TAN & Test Area North \\
\hline TSF & Technical Support Facility \\
\hline $\mathrm{USC}$ & United States Code \\
\hline VOC & volatile organic compound \\
\hline WAC & waste acceptance criteria \\
\hline WAG & waste area group \\
\hline WRRTF & Water Reactor Research Test Facility \\
\hline
\end{tabular}




\section{Explanation of Significant Differences for the Record of Decision for the Test Area North Operable Unit 1-10}

\section{INTRODUCTION}

This Explanation of Significant Differences (ESD) applies to the remedial actions performed under the Final Record of Decision for Test Area North, Operable Unit 1-10, Idaho National Engineering and Environmental Laboratory (DOE-ID 1999) as amended by the Explanation of Significant Differences for the Record of Decision for the Test Area North Operable Unit 1-10 (DOE-ID 2003), the Record of Decision Amendment for the V-Tanks (TSF-09 and TSF-18) and Explanation of Significant Differences for the PM-2A Tanks (TSF-26) and TSF-06, Area 10, at Test Area North, Operable Unit 1-10 (DOE-ID 2004a), and the Explanation of Significant Differences for the Record of Decision for the Test Area North Operable Unit 1-10 (DOE-ID 2005). The U.S. Department of Energy (DOE) Idaho Operations Office; U.S. Environmental Protection Agency (EPA), Region 10; and the Idaho Department of Health and Welfare - now identified as the Idaho Department of Environmental Quality (DEQ)signed the Record of Decision (ROD) in December 1999, the 2003 ESD in April 2003, the ROD Amendment/ESD in February 2004, and the 2005 ESD in January 2005. The EPA and DEQ support the need for this ESD.

This ESD - prepared in accordance with Section 117(c) of the "Comprehensive Environmental Response, Compensation, and Liability Act of 1980 (CERCLA/Superfund)," (42 USC 9601 et seq.) and Section 300.435(c)(2)(i) of the "National Oil and Hazardous Substances Pollution Contingency Plan," (40 CFR 300)-documents significant changes to portions of the remedies selected in the following decision documents: 1999 ROD, modified in a 2003 ESD, the 2004 ROD Amendment/ESD, and the 2005 ESD for sites at the Test Area North (TAN) Technical Support Facility (TSF). The site and remedy changes addressed in this ESD include the following:

TSF-18 V-9 Tank-The change to the remedy selected for the remaining V-9 waste includes:

- The remaining V-9 waste will be managed separately from the larger TSF-09/18 consolidated waste stream, instead of as specified in previous decision documents.

- A site-specific treatment variance is granted in accordance with 40 CFR 268.44(h)(2) establishing an alternate concentration-based treatment standard for high-mercury V-9 wastes of $0.20 \mathrm{mg} / 1$ TCLP which replaces the technology specific treatment standard of RMERC or IMERC. All other applicable treatment requirements must be met prior to land disposal of this waste.

- Treatment to meet the alternate concentration-based treatment standard will take place at an offsite, out-of-state, RCRA permitted treatment facility.

- Waste treated subject to the alternate concentration-based treatment standard must be disposed of at the Idaho CERCLA Disposal Facility (ICDF) upon confirmation of compliance with all applicable LDR treatment requirements and with the ICDF Waste Acceptance Criteria (WAC).

The amended remedy remains protective of human health and the environment, complies with Federal and State applicable or relevant and appropriate requirements identified in the 1999 ROD and amended in the 2004 ROD Amendment/ESD, is cost effective and addresses the principal threat through treatment. The amended remedy satisfies $\S 121$ of CERCLA. 
The remaining sites and remedies discussed in the previous decision documents are not affected by this ESD. This ESD will become part of the Idaho National Laboratory (INL) administrative record. Significant sections of the INL administrative record are on the Internet at http://ar.inel.gov/ and are available to the public at the following locations:

\author{
INL Technical Library \\ DOE Public Reading Room \\ 1776 Science Center Drive \\ Idaho Falls, ID 83415 \\ (208) 526-1185
}

\author{
Albertson's Library \\ Boise State University \\ 1910 University Drive \\ Boise, ID 83725 \\ (208) 426-1625
}

\section{SUMMARY OF SITE HISTORY, CONTAMINATION, AND SELECTED REMEDY}

\subsection{Site History}

The INL, which is managed by the U.S. Department of Energy (DOE), is a government facility located $51 \mathrm{~km} \mathrm{(32} \mathrm{mi)} \mathrm{west} \mathrm{of} \mathrm{Idaho} \mathrm{Falls,} \mathrm{Idaho.} \mathrm{The} \mathrm{INL} \mathrm{Site} \mathrm{occupies} 2,305 \mathrm{~km}^{2}\left(890 \mathrm{mi}^{2}\right)$ of the northeastern portion of the Eastern Snake River Plain. In 1949, the U.S. Atomic Energy Commission established the site as the National Reactor Testing Station. The purpose was to conduct nuclear energy research and related activities. In 1974, the National Reactor Testing Station was redesignated the Idaho National Engineering Laboratory; in 1997, it was renamed the Idaho National Engineering and Environmental Laboratory to reflect expansion of its mission to include a broader range of engineering and environmental management activities. In 2004 the name was again changed to the Idaho National Laboratory. The developed area within the INL Site is surrounded by a 13- $\mathrm{km}^{2}\left(5-\mathrm{mi}^{2}\right)$ buffer zone used for cattle and sheep grazing. The county land surrounding the INL Site is approximately $45 \%$ agricultural, $45 \%$ open land, and $10 \%$ urban. Sheep, cattle, hogs, and poultry are produced. In addition, potatoes, sugar beets, wheat, barley, oats, forage, and seed crops are cultivated. Most of the land surrounding the INL Site is owned by private individuals or the U.S. government.

The Test Area North (TAN) facility is located in the northern portion of the INL Site (see Figure 1), and the nearest communities are Howe (west) and Mud Lake (east). The TAN Technical Support Facility (TSF) was constructed between 1954 and 1961 to support the Aircraft Nuclear Propulsion Program. The program's objectives were to develop and test designs for nuclear-powered aircraft engines. Upon termination of this research in 1961, TAN's facilities were converted to support a variety of other DOE research projects. From 1962 through 1986, the area supported reactor safety testing at the Loss-of-Fluid Test (LOFT) Facility, Initial Engine Test (IET) Facility, and the Water Reactor Research Test Facility (WRRTF) shown in Figure 2. Beginning in 1980, the area was used to conduct work with material from the 1979 Three-Mile Island reactor accident. Most of the facilities at TAN are either inactive or are in the process of being removed. The remaining activities at TAN include the manufacture of armor for military vehicles at the Specific Manufacturing Capability (SMC) Project.

\subsubsection{V-9 Tank Site (TSF-18)}

The V-9 Tank (TSF-18) has been addressed in previous decision documents as part of the TSF-09/18 V-Tanks remediation project. The V-9 Tank (TSF-18) as well as the V-1, V-2, and V-3 Tanks TSF-18 received radioactively contaminated wastes from multiple sources until the late 1970 's. The primary sources of waste included the IET facility, the TAN Decon Shop, the TAN Hot Shop, and the TAN Hot Cells. 


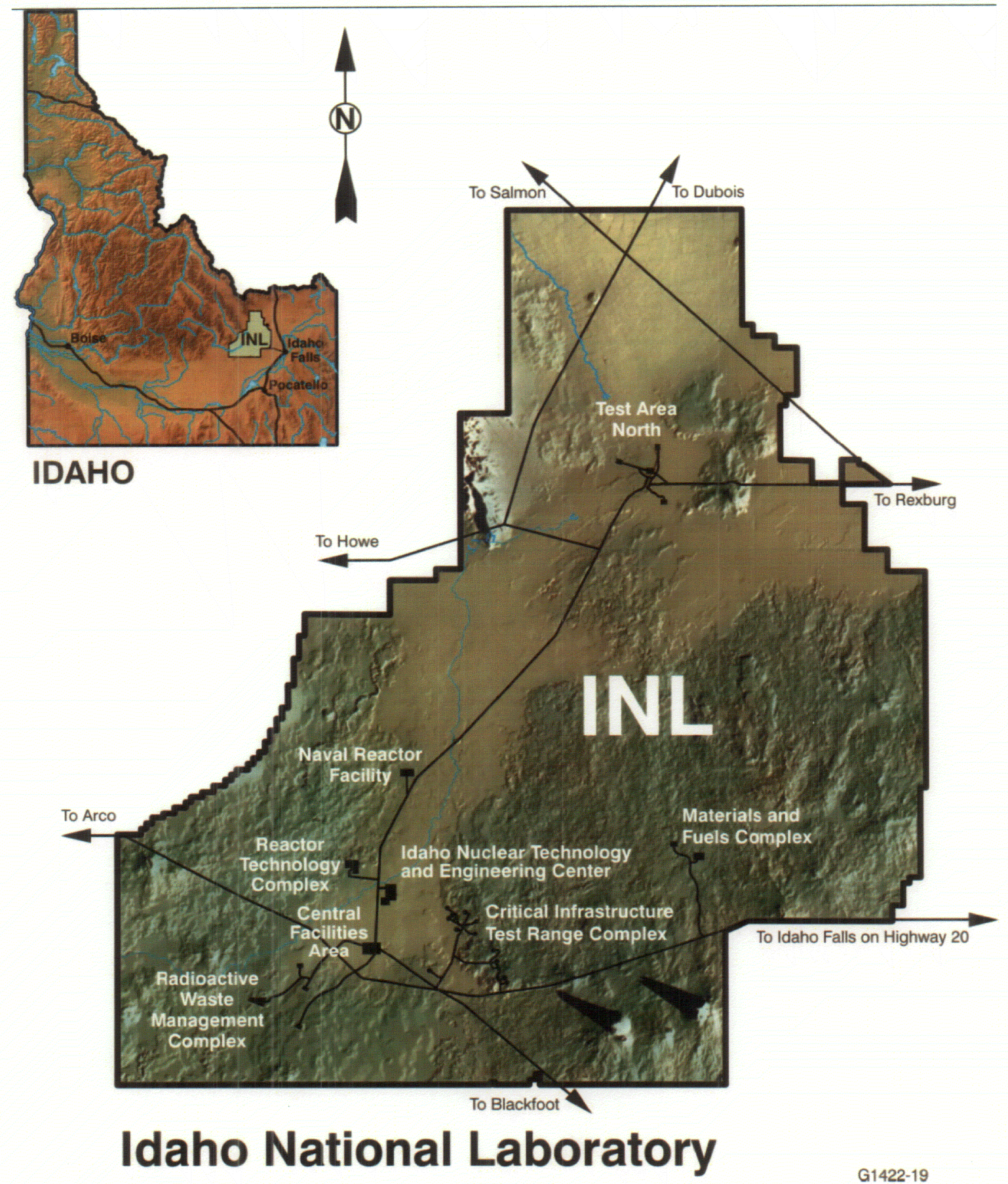

Figure 1. Location of areas and facilities at the INL Site. 


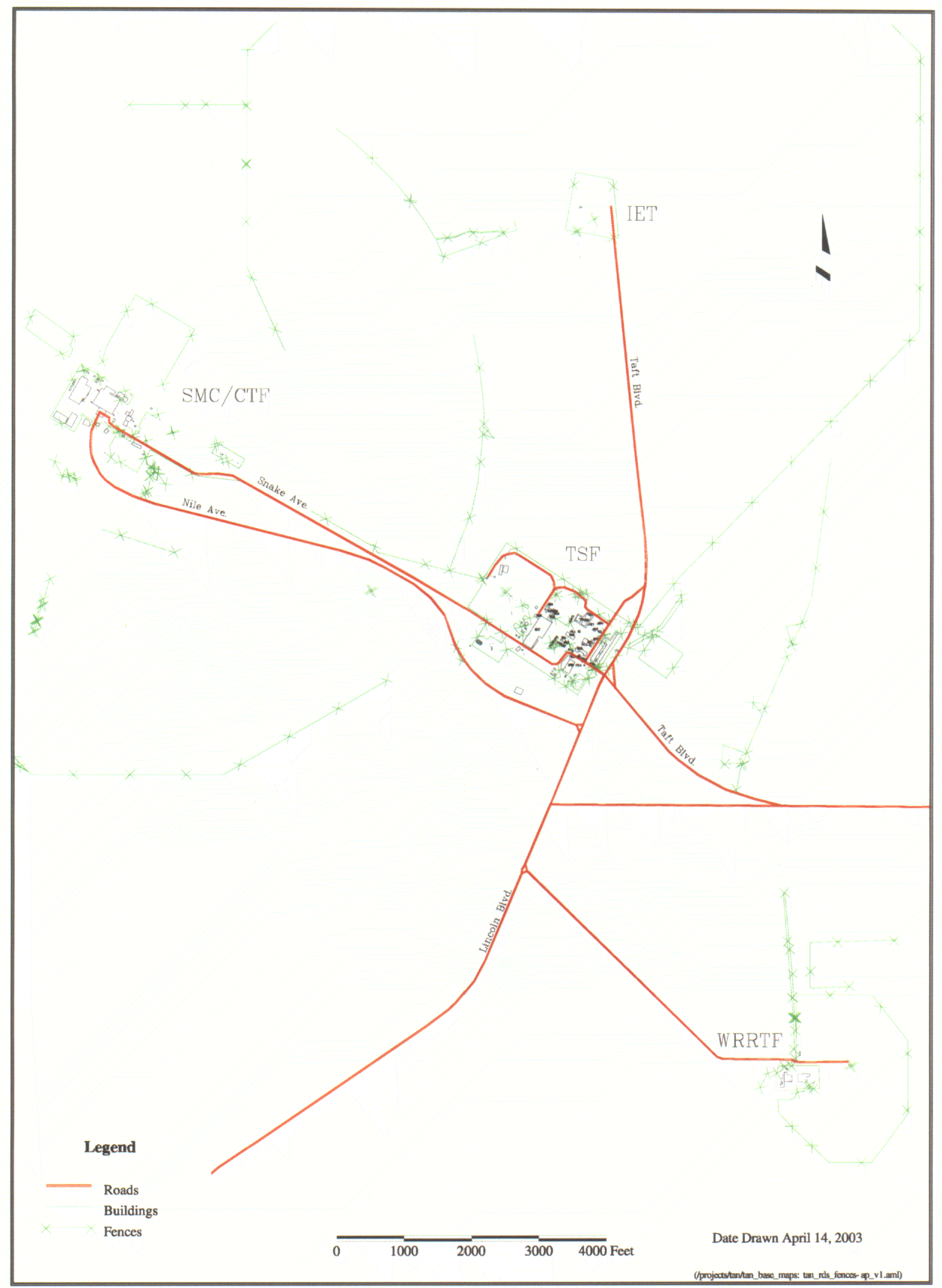

Figure 2. Location of individual facilities at TAN. 


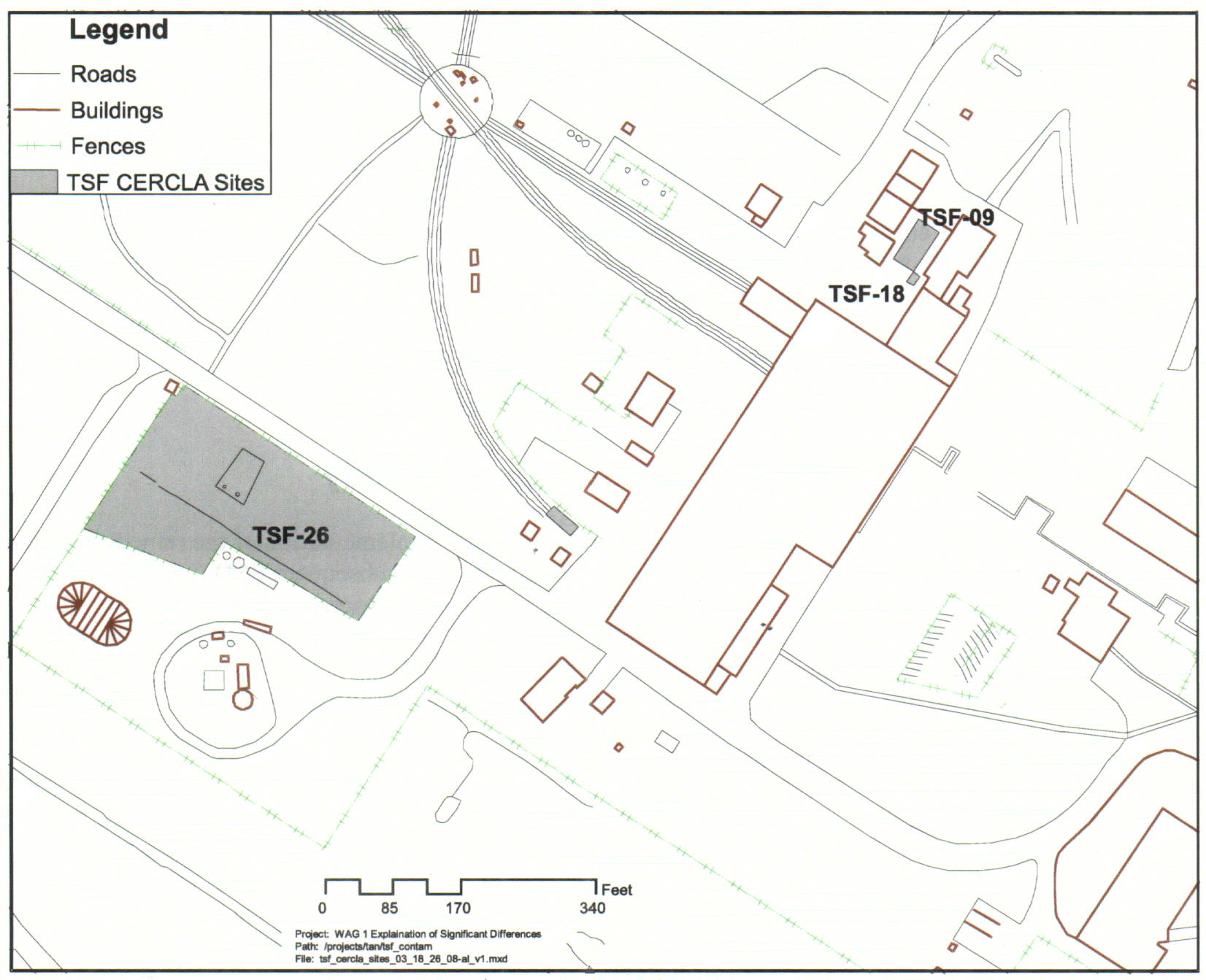

Figure 3. Location of the V-9 Tank Site (TSF-18).

\subsection{Contamination in Accordance with the 1999 Record of Decision}

The V-9 Tank (TSF-18) is an abandoned 1,514-L (400-gal) underground storage tank. The multitude of waste sources contributing to the V-Tanks (including the V-9 Tank) led to a complex mixture of highly radioactive and hazardous waste. These wastes were classified as F001 waste containing high concentrations of Trichloroethylene, Tetrachloroethylene, and 1,1,1-Trichloroethane. The potential for the presence of elemental mercury was recognized. 


\subsection{Selected Remedy in Accordance with the 2005 Explanation of Significant Differences}

The selected remedy, as defined in the Explanation of Significant Differences for the Record of Decision for the Test Area North Operable Unit 1-10 (DOE-ID 2005) identified the remedy for the consolidated V-Tanks waste based upon sparging of the consolidated V-Tanks waste stream in order to remove the listed F001 constituents with additional treatment (e.g. solidification, stabilization) as necessary to meet ICDF or other approved disposal facility waste acceptance criteria. If the sparging was ineffective then chemical oxidation of the waste was specified.

\section{DESCRIPTIONS AND BASIS OF THE SIGNIFICANT DIFFERENCES}

\subsection{V-9 Tank Changed Remedy}

For the V-9 Tank, this ESD identifies changes regarding the implementation of the remedy selected in the ROD Amendment/ESD (DOE-ID 2004a) and as modified in the subsequent ESD (DOE-ID 2005). This remedy change provides for the remaining V-9 waste to be managed separately from the overall consolidated V-Tank waste stream. This change provides a treatment variance establishing an alternate treatment requirement for D009 mercury present in the remaining V-9 waste. This ESD also provides for treatment to occur at an off-site location with the waste being returned for disposal at ICDF. See Table 1.

Table 1. Summary of changes for the V-9 Tank (TSF-18).

\begin{tabular}{|l|l|l|}
\hline Remedial Action Element & \multicolumn{1}{|c|}{ Original/Amended Remedy } & \multicolumn{1}{c|}{ Remedy Change } \\
\hline Treatment approach & $\begin{array}{l}\text { 4. Air sparging at ambient or } \\
\text { elevated temperatures (up to and } \\
\text { including boiling temperatures) of } \\
\text { V-Tanks contents, chemical } \\
\text { oxidation/reduction as necessary, } \\
\text { and solidification/ stabilization to } \\
\text { meet RCRA LDR treatment } \\
\text { standards as well as ICDF or other } \\
\text { approved disposal facility WAC. }\end{array}$ & $\begin{array}{l}\text { No significant change however the } \\
\text { remaining V-9 waste will be managed } \\
\text { separately from the overall consolidated } \\
\text { V-Tanks waste stream. }\end{array}$ \\
\hline $\begin{array}{l}\text { Alternative Treatment Standard } \\
\text { for D009 Mercury High } \\
\text { Subcategory }\end{array}$ & Not specified & $\begin{array}{l}\text { A Site-Specific Treatment Variance } \\
\text { establishes an alternative mercury } \\
\text { treatment standard for the remaining V-9 } \\
\text { waste. This waste shall be treated to } \\
\text { reduce the TCLP-Hg content to less than } \\
\text { 0.20 mg/L. }\end{array}$ \\
\hline Treatment location & $\begin{array}{l}\text { Treatment was to take place at or } \\
\text { adjacent to the Area of } \\
\text { Contamination }\end{array}$ & $\begin{array}{l}\text { Treatment to meet the alternative } \\
\text { concentration based treatment standard } \\
\text { will occur at an off-site out-of-state } \\
\text { treatment facility. }\end{array}$ \\
\hline Disposal & $\begin{array}{l}\text { Disposal in the ICDF or other } \\
\text { approved disposal facility }\end{array}$ & $\begin{array}{l}\text { The treated waste will be returned to the } \\
\text { INL and disposed at the ICDF after } \\
\text { confirmation of compliance with the LDR } \\
\text { treatment standards, including the } \\
\text { alternative treatment standard established } \\
\text { through this ESD, and the ICDF WAC. }\end{array}$ \\
\hline
\end{tabular}




\title{
3.1.1 Revised Treatment Approach
}

Additional sampling has determined that the remaining waste from the V-9 tank is characterized as D009 waste because the waste exhibits the characteristic of toxicity for mercury (greater than $0.20 \mathrm{mg} / \mathrm{L}$ TCLP Hg). This remaining V-9 waste also contains greater than $260 \mathrm{mg} / \mathrm{kg}$ of total mercury. Difficulty in removing and treating the remaining V-9 waste as well the finding of unexpected mercury levels has led to the decision to treat the remaining V-9 waste separately from the larger V-tanks consolidated waste stream. The remaining V-9 waste requires treatment since the contents represent a principal threat under CERCLA. The remaining V-9 waste consists of the remaining tank contents, excess sample material, and waste removed from associated piping ancillary to the V-9 tank. This waste also requires further treatment for F001 contaminants (Trichloroethylene, Tetrachloroethylene, and 1,1,1-Trichloroethane).

\subsubsection{Alternative Treatment Standard}

The ARARs associated with the existing remedy require compliance with the existing LDR treatment standard. The existing LDR treatment requirement for radioactively contaminated D009 waste containing greater than $260 \mathrm{mg} / \mathrm{kg}$ of total mercury is RMERC (roasting or retorting with mercury recovery) or IMERC (incineration with mercury recovery). A review of the RMERC and IMERC method of treatment standards indicates that neither technology is appropriate to apply to the D009 V-9 wastes, demonstrating the need for a treatability variance as a means to establish an alternate treatment standard that is appropriate under 40 CFR $268.44(\mathrm{~h})(2)$.

The remaining V-9 waste has been determined to exhibit the characteristic of toxicity for mercury (D009) and to contain greater than $260 \mathrm{mg} / \mathrm{L}$ total mercury. The Environmental Protection Agency (EPA) established the LDR treatment standard for this type of waste as either RMERC or IMERC in 40 CFR 268.40. These treatment standards were established in order to promote the reuse or recycling of elemental mercury.

\begin{abstract}
RMERC $=$ Retorting or roasting in a thermal processing unit capable of volatilizing mercury and subsequently condensing the volatilized mercury for recovery. The retorting or roasting unit (or facility) must be subject to one or more of the following: (a) a National Emissions Standard for Hazardous Air Pollutants (NESHAP) for mercury; (b) a Best Available Control Technology (BACT) or a Lowest Achievable Emission Rate (LAER) standard for mercury imposed pursuant to a Prevention of Significant Deterioration (PSD) permit; or (c) a state permit that establishes emission limitations (within meaning of section 302 of the Clean Air Act) for mercury. All wastewater and nonwastewater residues derived from this process must then comply with the corresponding treatment standards per waste code with consideration of any applicable subcategories (e.g., High or Low Mercury Subcategories).
\end{abstract}

IMERC $=$ Incineration of wastes containing organics and mercury in units operated in accordance with the technical operating requirements of 40 CFR part 264 subpart 0 and part 265 subpart 0 . All wastewater and nonwastewater residues derived from this process must then comply with the corresponding treatment standards per waste code with consideration of any applicable subcategories (e.g., High or Low Mercury Subcategories).

EPA regulations state that a Site-Specific Treatment Variance may be granted if it is determined that a specific method of treatment is inappropriate, even though such treatment is technically possible. See 40 CFR 268.44(h)(2). An evaluation of the application of either RMERC or IMERC to high mercury subcategory D009 waste determined that these treatment technologies are inappropriate when applied to radioactively contaminated waste. EPA documented this in a Determination of Equivalent Treatment issued to Brookhaven National Laboratory in 1998 (EPA 1998). 
In the context of this treatability study situation, roasting or retorting and recovery of mercury (RMERC) from High Mercury-Inorganic nonwastewater wastes does not appear to be an appropriate treatment method if the wastes are also radioactive. This is because the recovered mercury is expected to be still classified as radioactive material and as such will not be recyclable but will require further treatment prior to its ultimate disposal. Therefore, the earlier recovery step appears not to serve a useful purpose in this particular mixed waste context, and would involve additional waste handling with the attendant concerns about potential exposure to radionuclides.

EPA continues to take this position as evidenced by their use of radioactively contaminated high mercury D009 as the exemplar waste stream for the application of a treatment variance (EPA 2006).

For example, a variance may be appropriate for a high mercury subcategory waste that also is radioactive (i.e., a mixed waste). The current regulations require high mercury-organic subcategory mixed wastes be treated by a retorting mercury recovery process (RMERC) or by incineration (IMERC) and high mercuryinorganic subcategory mixed wastes be treated by RMERC. However, it would generally not be appropriate to recover mercury from mixed wastes because there is no use for recovered mercury that is radioactively contaminated.

To manage this type of waste it would appear reasonable to use, on a site-specific basis, the "inappropriate" variance approach. Rather than recovering the mercury from such waste, a petitioner could seek to treat and dispose of the waste. Such a petitioner would have to describe the specifics and likely effectiveness of the stabilization treatment that will be used.

In the above referenced Determination of Equivalent Treatment EPA required that the waste meet the alternative treatment standard of $0.20 \mathrm{mg} / \mathrm{L} \mathrm{TCLP}-\mathrm{Hg}$ (EPA 1998) prior to disposal.

The requested replacement standard for the limited quantity of waste to be subject to the Treatability studies is the current LDR concentration-based treatment standard for Low Mercury-Inorganic nonwastewaters that have undergone RMERC, $0.20 \mathrm{mg} / L$ TCLP. Therefore, the wastes will be subject to treatment standards equivalent to those for the residues of the RMERC process, but without having to first undergo a non-useful RMERC step. This is an appropriate measure of equivalent performance and is sufficiently protective of human health and the environment in this particular situation.

Treatment of the remaining V-9 waste by the method specified as the treatment standard (RMERC or IMERC) is technically inappropriate, even though such treatment is technically possible. The rationale for this determination is that both RMERC and IMERC technologies involve relatively high-temperature thermal treatment, and such treatment would be inappropriate considering the radioactive nature of the V-9 wastes. In addition, RMERC would be inappropriate since there is no known use for radioactivelycontaminated mercury that would be recovered from an application of this method of treatment.

The Agencies have made the determination that an alternative concentration-based treatment standard of $0.20 \mathrm{mg} / \mathrm{L} \mathrm{TCLP}-\mathrm{Hg}$ is sufficient to minimize threats to human health and the environment posed by land disposal of the wastes. As documented above, EPA has already determined that treatment to a concentration standard of $0.20 \mathrm{mg} / 1 \mathrm{TCLP}$, the treatment standard for the low-mercury residues from RMERC treatment, provides a measure of performance equivalent to that achieved by RMERC or IMERC for radioactive wastes otherwise subject to the high-mercury subcategory. Through its initial promulgation of the $0.20 \mathrm{mg} / 1$ TCLP standard for RMERC residues, EPA determined that this standard satisfies the statutory requirement of Section 3004(m) of RCRA, which requires that LDR treatment standards minimize threats to human health and the environment posed by land disposal. With respect to this treatability variance, an alternate concentration-based treatment standard for high-mercury V-9 wastes of $0.20 \mathrm{mg} / 1 \mathrm{TCLP}-\mathrm{Hg}$ also satisfies the regulatory requirement of $40 \mathrm{CFR} 268.44(\mathrm{~m})$. All other applicable treatment requirements must be met prior to land disposal of this waste. 


\subsubsection{Addition of Potential Treatment Location}

The remedy as modified in the ROD Amendment/ESD specified treatment at or adjacent to the V-Tanks Site (TSF-09/18). Due to the demolition of the surrounding buildings and facilities further treatment at or adjacent to the V-Tanks site may not be achievable. The preferred option for treatment is to have this work performed at an off-site out-of-state treatment facility. Three companies have been identified as having the appropriate licenses and permits to meet the treatment requirements including Pacific Eco-Solutions (PECOS) of Richland, WA; Perma-Fix of Oak Ridge, TN; and Waste Control Specialists of Andrews, TX. PECOS is currently under contract to perform the treatment of the V-9 waste necessary to meet the existing F001 treatment standard as well as the alternative D009 treatment standard. PECOS plans on utilizing chemical oxidation and mercury stabilization technologies to meet these concentration based standards.

\subsubsection{Disposal}

All high mercury subcategory D009 waste treated to the alternative treatment standard of $0.20 \mathrm{mg} / \mathrm{L}$ are required to be disposed in the ICDF. All other wastes will be treated to the existing applicable LDR treatment standard and applicable waste acceptance criteria prior to disposal. Other wastes could include PPE, wipes, off-gas residues, returned sample material, and other miscellaneous waste materials. Disposal of this waste meeting existing applicable LDR treatment requirements and disposal facility WAC will be at the ICDF or other approved disposal facility. Some wastes including minor volumes of returned laboratory sample materials may be aggregated or consolidated to the extent practical in order to determine appropriate management, application of treatment standards, and disposal requirements.

\subsection{Rough Order of Magnitude Cost Estimate}

The changes to the V-9 Tank remedy as addressed in this ESD have been considered with respect to the most recent update of the estimated cost for the V-Tanks remedial action. The total estimated cost for the modified remedy described in the February 2004 ROD Amendment/ESD was $\$ 32.6 \mathrm{M}$. The rough order of magnitude total estimated cost for the remedy as addressed in the 2005 ESD was reduced to approximately $\$ 20.0 \mathrm{M}$ for air sparging treatment and to $\$ 22.5 \mathrm{M}$ for chemical oxidation treatment, if required. Air sparging treatment was successful for treating the majority of the consolidated V-Tank waste. For the remaining V-9 Tank waste, the estimated cost for treatment at the PECOS facility using chemical oxidation and mercury stabilization is approximately $\$ 480 \mathrm{~K}$. This cost is well within the range of the most recent estimate of $\$ 20.0$ to $\$ 22.5 \mathrm{M}$ provided in the $2005 \mathrm{ESD}$.

\section{AGENCY COMMENTS}

The EPA and the DEQ have reviewed this ESD and support the changes to the selected remedies for the identified OU 1-10 sites.

\section{PUBLIC PARTICIPATION}

The DOE will publish a notice of availability and a brief description of this ESD in the local newspaper (the Idaho Falls Post Register) and six other Idaho newspapers to meet the requirements of 40 CFR 300.435(c)(2)(i). The INL Community Relations Office may be contacted at (208) 526-4700 or (800) 708-2680. There will be no formal comment period. If requested by stakeholder groups, specific review sessions will be provided. 


\section{AFFIRMATION OF THE STATUTORY DETERMINATIONS}

The DOE, EPA, and DEQ believe, after reviewing the proposed changes to the selected remedy, that the remedy remains protective of human health and the environment, complies with federal and state requirements identified in the ROD as applicable or relevant and appropriate to the remedial action at the time of the final ROD, and is cost-effective. In addition, permanent solutions and alternative treatment technologies are included in the revised remedy to the maximum practicable extent.

\section{REFERENCES}

40 CFR 300, 2004, "National Oil and Hazardous Substances Pollution Contingency Plan," Code of Federal Regulations, Office of the Federal Register, October 4, 2004.

40 CFR 300.435 (c)(2)(i), 2004, "Remedial Design/Remedial Action, Operation and Maintenance," Code of Federal Regulations, Office of the Federal Register, September 30, 2004.

42 USC 6901 et seq., 1976, "Resource Conservation and Recovery Act of 1976," as amended.

42 USC 9601 et seq., 1980, “Comprehensive Environmental Response, Compensation, and Liability Act of 1980 (CERCLA/Superfund)," United States Code, December 11, 1980.

DOE-ID, 1999, Final Record of Decision for Test Area North, Operable Unit 1-10, Idaho National Engineering and Environmental Laboratory, DOE/ID-10682, Revision 0, U.S. Department of Energy Idaho Operations Office, October 1999.

DOE-ID, 2003, Explanation of Significant Differences for the Record of Decision for the Test Area North Operable Unit 1-10, DOE/ID-11050, Revision 0, U.S. Department of Energy Idaho Operations Office, April 2003.

DOE-ID, 2004a, Record of Decision Amendment for the V-Tanks (TSF-09 and TSF-18) and Explanation of Significant Differences for the PM-2A Tanks (TSF-26) and TSF-06, Area 10, at Test Area North, Operable Unit 1-10. DOE/ID-10682 Amend, Revision 0, U.S. Department of Energy Idaho Operations Office, February 2004.

DOE-ID, 2005, Explanation of Significant Differences for the Record of Decision for the Test Area North Operable Unit 1-10, DOE/NE-ID-11199, Revision 0, U.S. Department of Energy Idaho Operations Office, January 2005.

EPA, 1998, Elizabeth Cotsworth letter approving Determination of Equivalent Treatment for Brookhaven National Laboratory, U.S. Environmental Protection Agency, July 1, 1998.

EPA 2006, Variances and Determinations of Equivalent Treatment, EPA Website, http://www.epa.gov/epaoswer/hazwaste/mercury/vdet.htm downloaded October 22, 2006.

Utah, 2006, Letter from Dennis R. Downs, Executive Secretary of Utah Solid and Hazardous Waste Control Board to Tye K. Rogers, Vice President of Envirocare, January 19, 2006. 